\title{
Lesson learned: the model and policy strategy for developing sustainable renewable energy for agricultural communities
}

\author{
Dessy Rachmawatie ${ }^{1,{ }^{*}}$, Ernan Rustiadi ${ }^{2}$, Akhmad Fauzi $^{3}$ and Bambang Juanda ${ }^{3}$ \\ ${ }^{1}$ Faculty of Economics and Business, Universitas Muhammadiyah Yogyakarta, Yogyakarta, Indonesia \\ ${ }^{2}$ Facuty of Agriculture, IPB University, Bogor, Indonesia \\ ${ }^{3}$ Faculty of Economics and Management, IPB University, Bogor, Indonesia
}

\begin{abstract}
Lack of access to electricity is seen as a significant constraint to economic growth and increased welfare in developing countries. Most literature agrees that access to electricity is necessary for poverty alleviation. It is to be expected, given that researchers must deal with multi-factorial systems, where energy is only one of a linked set of variables that determine poverty outcomes. The most frequently reported causal chain linking access to electricity to poverty's impacts is to improve productivity or output of enterprises using electricity for their activities. Yogyakarta is one of the provinces in Indonesia that does not have the potential for fossil energy. This research was designed as a survey of 68 respondents who were electricity beneficiaries in Pantai Baru. Structural Equation Modeling-Partial Least Squares (SEM-PLS) was employed to analyze 23 indicators. The paper's novelty is on the method used in formulating the development of rural communities, which was then outlined by the Structural Equation Method - Partial Least Square, resulting in many key factors that affect empowerment improvement and agricultural community development. This study revealed critical variables in empowering rural communities, especially in utilizing renewable electricity, to encourage rural communities' development.
\end{abstract}

\section{Introduction}

Provision of access to electricity for villages is a strategic program for the following reasons: [1] Electricity is one of the basic needs of the community so that the government can use the provision of access to electricity as an effort to meet the whole community's basic needs, both those who are living in cities and villages. However, it is expected that the existence of electricity in the villages can empower rural communities from the backwardness and limitations of rural communities in accessing electricity. [2] Providing access to electricity for villages is expected to reduce disparities between villages and cities as disparities between regions.

Hopefully, the existence of access to electricity in the villages can create village economic growth and encourage rural communities' economic development. Therefore, access to electricity for rural communities is expected to empower rural communities, reduce poverty, and improve rural communities' welfare. The more specific definition of empowerment leads to increased community's ability, capacity, productivity, creativity, and independence to get greater opportunities to access and control various resources. Thus, it can be concluded that empowerment is not actually a development goal but a tool to achieve development goals [1].

One of the essential pillars that contribute to the development of renewable hybrid electric energy in Pantai Baru is through the empowerment of electricity beneficiaries of Hybrid Power Plants (HEPP). Since this location was developed as a HEPP electric energy development location, it has changed the face of Pantai Baru into a potential new tourism development area to be developed in Bantul Regency $[2,3]$. After the construction of HEPP electricity was carried out in Pantai Baru, many community empowerment programs have entered the area, both empowerment programs from the central

\footnotetext{
${ }^{*}$ Corresponding author : d.rachmawatie@umy.ac.id
} 
government, regional government, and academic. The empowerment program is directed to electricity beneficiaries based on their potential and needs.

Renewable hybrid energy is a combination of two or more energy sources used to provide electricity [4]. The purpose of developing this concept in the regions is to utilize renewable energy sources (EBT). The merging of the energy system is since not all EBTs can work optimally. For example, the solar energy system (photovoltaic) at night or in the rainy season does not produce electricity, but this energy source is maximum during the dry season. Likewise, for the source of electrical energy derived from wind energy, the electricity production generated cannot always be maximized because the influence of weather is very important in this system. Therefore, the hybrid power generation system (HEPP) derived from solar energy and wind energy is very appropriate developed in remote areas that are difficult to reach by the PLN grid system [5]. Several studies affirmed that the use of new renewable energy hybrid systems could reduce dependence on diesel generators in remote areas $[6,7,8]$. Thus, the existence of a renewable hybrid energy system in rural areas is beneficial for rural communities in encouraging economic activities in rural areas, for example: for street lighting, water supply, making ice for preservation of fish caught by fishers, education and skills, tourism, and other small businesses in rural areas.

The main problem in this study is whether the existence of a Hybrid Electric Power Plant (HEPP) provides socio-economic benefits for the HEPP electricity beneficiaries in particular and Poncosari Village residents in general. It is seen as a problem because [1] the Hybrid Power Plant's investment, and operating costs are not cheap, as much as IDR 3,715,727,160 per year has been spent by the local government (Mineral Resources Energy Office of Yogyakarta Special Region). [2] What about the sustainability aspects of the HEPP development program activities in the future so that the community's social and economic benefits can continue to be felt by rural communities. Therefore, an effort is needed to formulate an empowerment model and policy strategy to make it easier to determine the direction of empowerment programs for rural communities, primarily through the use of renewable energy to develop rural communities in the future. Specifically, the objectives of this study include the following: (1) knowing the benefits of the Structural Equation Modeling - Partial Least Square approach in the development of HEPP electricity in Pantai Baru; (2) formulating recommendations for community empowerment models in the development of renewable electricity; (3) formulating policy recommendations for developing sustainable renewable electricity; (4) knowing and analyzing the framework and mechanism for financing rural electricity programs

\section{Methods}

This research was designed with qualitative and quantitative research approaches. The method used in this study was a survey method through interview techniques to dig up information and obtain an explanation (explanatory) from respondents of electricity beneficiaries. The information was then analyzed to explain the relationship between variables and test hypotheses formulated previously in research. Besides, it was also for the purpose of further search (exploratory), namely understanding the experiences of key informants in the empowerment process carried out in Pantai Baru. The purpose of in-depth interviews was to complete various aspects of empowerment that had not been revealed through the questionnaire as a research instrument.

This research was conducted in November 2017 - December 2017. This research location was in Pantai Baru, Bantul Regency, Special Province of Yogyakarta. The site selection was based on considering that the location had HEPP electrical energy development activities initiated and maintained jointly by the community. This study's respondents were 68 business operators in Pantai Baru, who were the HEPP electricity beneficiaries.

This study's population was 68 consisted of individuals, including the Activity Group and Tourism Awareness Group members, who received direct benefits of HEPP electricity (tourism business operators) in Pantai Baru. The total respondents of this study were 68 respondents. This study's key informants totaled eight people, consisting of village and hamlet community leaders, Bantul Regency Government, Yogyakarta Provincial Energy Office, Bantul Regency Tourism Office, activity leaders, tourism awareness groups, and PLTS managers. This study's unit of analysis was the individual beneficiaries of HEPP electricity (tourism business operators in Pantai Baru) who were in the groups, both Activity Groups (POKGIAT) and Tourism Awareness (POKDARWIS) groups in Pantai Baru.

The type of data used in this study was primary and secondary data. This study's primary data were obtained directly from respondents through structured interviews using a questionnaire to 68 respondents. Primary data in this study were endogenous latent variables and exogenous latent observed in the study, including (1) Individual characteristics (X1): age, formal education, business experience, household income, and motivation; (2) Environment (X2): affordability of electricity costs, ease of 


\section{ICONARD 2020}

information, acceptability of hamlet residents to HEPP, and the ability of HEPP technicians; (3) Group support (X3): group leader leadership, training intensity, group participation, and appropriateness of training modules; (4) Level of empowerment (Y1): the ability to adapt, the ability to manage businesses, the ability to make decisions, and the ability to work together; (5) Village community development (Y2): access to electricity, access to clean water, business opportunities in the village, absorption of village labor, women's involvement in household income, and the cultural traditions of the local community.
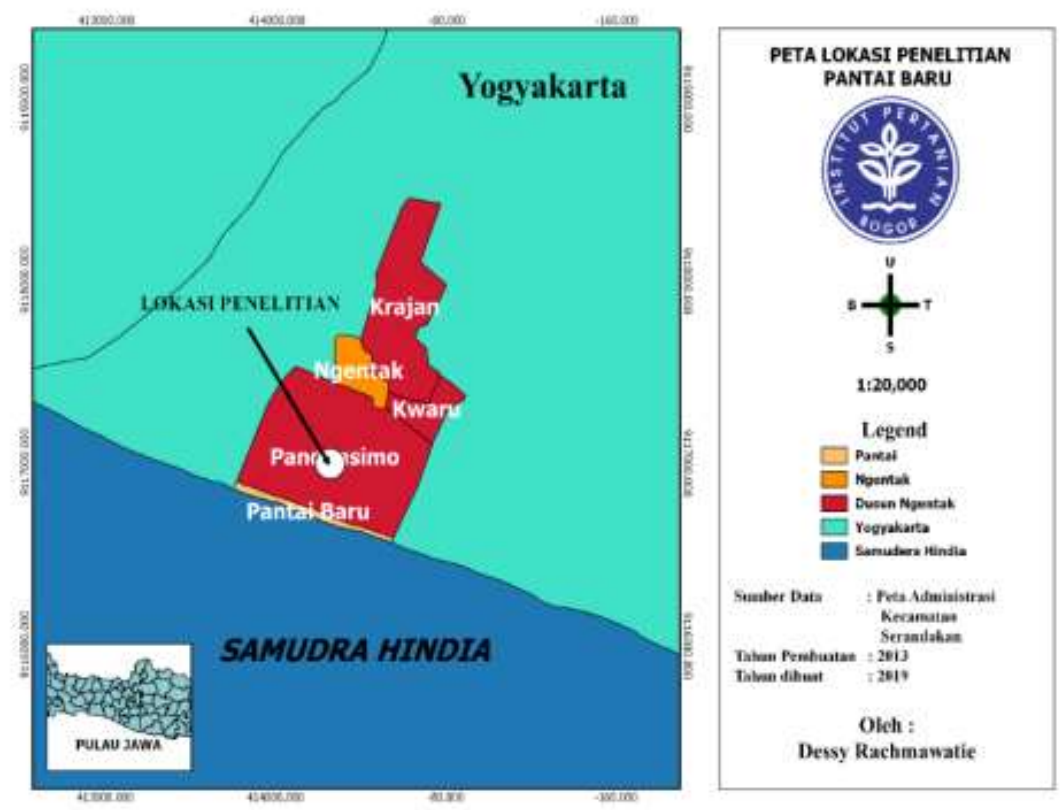

Source: [9]

Fig. 1. Research Location

Table 1. Latent Endogenous and Exogenous Variables along with the Indicators

\begin{tabular}{|l|l|}
\hline Latent Variable & Indicators \\
\hline Individual Characteristics $\left(\boldsymbol{X}_{\mathbf{1}}\right)$ & $X_{11}:$ Age \\
& $X_{12}:$ Education \\
& $X_{13}:$ Business Experiences \\
& $X_{14}:$ Households Income \\
& $X_{15}:$ Motivation \\
\hline Environment $\left(\boldsymbol{X}_{\mathbf{2}}\right)$ & $X_{21}:$ Affordability Cost Electricity \\
& $X_{22}:$ Accessibility Information \\
& $X_{23}:$ Acceptability of the Electricity HEPP \\
& Beneficiaries \\
& $X_{24}:$ Ability of HEPP Technician \\
\hline Supporting Groups $\left(\boldsymbol{X}_{\mathbf{3}}\right)$ & $X_{31}:$ Ability to Leadership \\
& $X_{32}:$ Intensity of Training and Coaching \\
& $X_{33}:$ Groups Participation \\
& $X_{34}:$ Suitability of the Training Module \\
\hline Empowerment $\left(\boldsymbol{Y}_{\mathbf{1}}\right)$ & $Y_{11}:$ Ability to Adaptation \\
& $Y_{12}:$ Ability to Business Management \\
& $Y_{13}:$ Ability to Making Decisions \\
& $Y_{14}:$ Ability to Cooperate \\
\hline Rural Community Development $\left(\boldsymbol{Y}_{\mathbf{2}}\right)$ & $Y_{21}:$ Access to Electricity \\
& $Y_{22}:$ Access to Clean Water \\
& $Y_{23}:$ Business Opportunity \\
& $Y_{24}:$ Absorption of Rural Workers \\
& $Y_{25}:$ Women's Involvement in Household \\
& $Y_{26}:$ Income \\
\hline
\end{tabular}


Secondary data were supporting data obtained from relevant agencies, which were relevant to the research, including those obtained from Consumer Price Index (CPI) and DIY Province Inflation in 20072017, Statistics Indonesia 2005-2017, Roadmap for Regional Innovation Systems Development Planning Agency Bantul Regency Area 2016-2021, and Monographs of Poncosari Village in 2018. The variables used in this study are presented in Table 1.

The stages of data analysis in this study generally consisted of two stages: 1) describing the data to obtain a general description of the empowerment level of HEPP electricity beneficiary respondents to a Likert scale of 1 (very low), 2 (low), 3 (moderate), and 4 (high), and 2) modeling SEM-PLS on a Likert scale. After the key variables influencing rural communities' empowerment in the utilization of hybrid electric energy were found, the next step was to make recommendations on the Model of Community Empowerment in Renewable Energy Development.

\section{Result and discussion}

The relationship between electricity use and development has been extensively studied from a macro and micro perspective; electricity development with local dimensions in nexus development and poverty, the rural context is not fully characterized. It is not quite as simple as merely providing access to electricity and giving "hope" to villagers in the name of development, only with their own help. Moreover, much literature indeed asserts that access to electricity must always coexist with other sustainable service activities, for example, by providing health services, skills, creating business activities in rural areas, gender equality, and increasing income at the village level $[10,11,12,13]$. Understanding community empowerment is a strategy that focuses on providing a proportional role so that the community can play an active role in social activities. Therefore, it is vital to focus on a suitable community empowerment policy model in sustainable renewable energy development.

\subsection{Structural equation modeling approach by partial least square in the development of hybrid energy electricity}

Figure 1 shows that this study's SEM-PLS model consisted of four endogenous variables: individual characteristics $\left(X_{1}\right)$, environment $\left(X_{2}\right)$, empowerment level $\left(Y_{1}\right)$ and rural community development $\left(Y_{2}\right)$, and one exogenous variable: group support $\left(X_{3}\right)$. Furthermore, in Figure 1 , there was an intervening variable or intermediating, the variable empowerment level of electricity beneficiaries $\left(Y_{1}\right)$, which has predecessor variables (previous variables): individual characteristics $\left(X_{1}\right)$, environment $\left(X_{2}\right)$, and group support $\left(X_{3}\right)$, and has one consequent variable (variable afterward) village community development $\left(Y_{2}\right)$.

In the latent variables of individual characteristics $\left(X_{1}\right)$, motivation indicators had the highest loading factor values, so this indicator had the highest contribution. In the latent environment variable $\left(X_{2}\right)$, the indicator with the highest contribution was the ease of information and awareness of hamlet residents in adopting HEPP electricity. Furthermore, in the latent variable of group support $\left(X_{3}\right)$, the indicator with the highest contribution was group training providers' ability. In the latent variable of the empowerment level $\left(Y_{1}\right)$, the indicator of interactional ability was the highest contribution. In the latent variable of the empowerment level, the indicator with the highest contribution was interpersonal ability. Furthermore, in latent variables of rural community development $\left(Y_{2}\right)$, the indicator with the highest contribution was the business opportunity variable.

Based on the Structural Equation Modeling analysis results in this study, it was indicated that group support was one of the variables with a direct and significant influence on the variables of individual characteristics, environment, and empowerment level, with a significance value above the cut-off value of 1.96. It signified that the higher the group support that HEPP beneficiaries received, their character would be better. The higher the group support, the better the environment, the affordability of HEPP electricity costs, ease of information, citizens' acceptability to HEPP, and HEPP technicians' ability. Moreover, the higher the group support obtained by HEPP electricity beneficiaries, the higher their empowerment level. The indicators of the highest empowerment level in the SEM model were the ability of HEPP electricity beneficiaries to make decisions $(0.968)$, the ability to manage a business $(0.958)$, the ability to collaborate (0.955), and the ability to adapt (0.841), successively.

Thus, the factor triggering HEPP electricity beneficiaries' high empowerment level in Pantai Baru was the role of community support groups. This factor had an immense contribution to the emergence of 
HEPP electricity beneficiaries' empowerment in Pantai Baru. The details are displayed in Table 2 as follows. Based on group theory in this study's context, HEPP electricity beneficiaries also acted as tourism businesses in Pantai Baru with a group's existence. Then, with groups' existence, they could interact with each other, exchange ideas with each other, support each other, and meet each other's needs. Moreover, through groups, they could develop themselves and their potentials and do self-actualization [14].

Therefore, in the long run, with groups' support, personal closeness, and certain attractions would be formed. Through closeness, attractiveness, common goals, and economic reasons, they can understand each other's potential that can be used to meet their needs [15]. In line with the elaboration, based on the study's results that discussed group empowerment mentioned that the factors influencing the low community empowerment were the low level of farmer participation in the group, inappropriate empowerment patterns, lack of physical and socio-economic environmental support, low characteristics of farmers, and lack of agricultural information that met farmers' needs.

Table 2. Direct and Indirect Effects of Empowerment of Electric Beneficiaries and Village Community Development Using SEM - PLS

\begin{tabular}{|l|l|l|l|l|l|l|}
\hline \multicolumn{1}{|c|}{ Relationship } & \multicolumn{1}{|c|}{$\begin{array}{c}\text { Path } \\
\text { coefficient }\end{array}$} & $\begin{array}{c}\text { Standard } \\
\text { error }\end{array}$ & \multicolumn{1}{c|}{$\begin{array}{c}\text { T } \\
\text { statistic }\end{array}$} & $\begin{array}{c}\text { Cuts off } \\
(\boldsymbol{\alpha}=\mathbf{5 N U})\end{array}$ & \multicolumn{1}{|c|}{ Conclusion } \\
\hline & 0.150 & 0.092 & 5.321 & $\geq 1.96$ & Significant \\
\hline $\begin{array}{l}\text { Supporting Groups }\left(\boldsymbol{X}_{\mathbf{3}}\right)-> \\
\text { Personal Characteristic }\left(\boldsymbol{X}_{\mathbf{1}}\right)\end{array}$ & 0.912 & 0.056 & 16.188 & $\geq 1.96$ & Significant \\
\hline $\begin{array}{l}\text { Supporting Groups }\left(\boldsymbol{X}_{\mathbf{3}}\right)-> \\
\text { Environment }\left(\boldsymbol{X}_{\mathbf{2}}\right)\end{array}$ & 0.676 & 0.008 & 112.003 & $\geq 1.96$ & Significant \\
\hline $\begin{array}{l}\text { Supporting Groups }\left(\boldsymbol{X}_{\mathbf{3}}\right)-> \\
\text { Empowerment }\left(\boldsymbol{Y}_{\mathbf{1}}\right)\end{array}$ & 0.776 & 0.055 & 14.071 & $\geq 1.96$ & Significant \\
\hline $\begin{array}{l}\text { Empowerment }\left(\boldsymbol{Y}_{\mathbf{1}}\right)->\text { Rural } \\
\text { Community Development }\left(\boldsymbol{Y}_{\mathbf{2}}\right)\end{array}$ & \multicolumn{7}{|c|}{ Indirect Effect } \\
\hline
\end{tabular}

Source: [9]

The advantage of HEPP electrical energy development activities in Pantai Baru was that this activity was carried out through the socio-cultural approach of local hamlet residents so that it did not eliminate the existing order. Supported by various groups in Poncosari Village, the community received socialization and technical guidance from academics involved in this activity. In Ngentak Hamlet, Poncosari Village, there were Community Activities Groups (POKGIAT), including Farmers Groups, Fishermen Groups, Livestock Groups, and Youth Organizations Groups. After the construction of HEPP and hybrid electric energy began to run, several groups were then developed, such as the Culinary Groups, Tourism Awareness Group (POKDARWIS), and other community groups, such as the turtle conservation community naturally developed by the local youth in Pantai Baru. The emergence of these community activity groups is an initiative of the local village residents, which initially originated from the community's initiative to access electricity in the coastal area, especially for the fishers' needs, such as creating ice makers for preserving the catches of fishers, farmers, and tourism, which have been in ruins in Pandansimo Beach after the Yogyakarta earthquake in 2008. This activity has indirectly driven the village economy by developing HEPP electricity packaged in the Regional Innovation System (SIDa).

\subsection{Recommendations for the Agricultural Community Empowerment Model in Renewable Electric Energy Development}

Models are representations of objects or ideas in a simplified form of conditions or natural phenomena. The model contains information about a phenomenon created to study the actual system phenomenon. The model can be an imitation of an object, system, or actual event that only contains information considered essential to be studied [15]. The purpose of modeling the village community empowerment in this section is to determine the information that is considered necessary and facilitate us in analyzing a problem, in this context related to the community empowerment process that has been carried out in the development of HEPP electricity in Pantai Baru. The purpose of the model built is to determine the strategy for empowering rural communities, such as what is effectively done in the context of developing renewable electricity, especially HEPP in the future. The type of model classification built in this study 
is closer to the empirical model, where the formulated model was obtained based on data and input or suggestions from the objective conditions in the field.

Based on the Structural Equation Modeling - Partial Least Square model obtained in the previous section, four pathways directly affected the empowerment level of HEPP electricity beneficiaries, namely variables: (1) group support for individual characteristics, (2) group support for the environment, (3) group support for the empowerment level, and (4) the empowerment level of HEPP electricity beneficiaries towards the development of village communities. This study's community support variable is a key variable in encouraging community empowerment and local village communities' development. With increased group support carried out by community group activist figures in the village community and those fostered by the local government, these efforts have proven to have a significant effect on the electricity beneficiaries' household income. Besides, the support of community groups variable also significantly influenced the HEPP environment, namely: HEPP electricity costs, ease of information, acceptance of citizens, and HEPP technicians' ability. The variable group support also affected community empowerment; the better the group support, the better the local community's empowerment. Therefore, this variable is a key variable in driving empowerment and encouraging local village communities' development.

Moreover, a pathway indirectly influenced rural community development, namely the variable group support on rural community development. The variable support for this group had an indirect effect on village communities' development through better community empowerment. The following is the SEMPLS model using SmartPLS version 2.0, obtaining variables that affected HEPP electricity beneficiaries' empowerment and rural community development. It is shown in Figure 2.

The weakness of the program activities carried out under the project was the activity program's sustainability for local communities, which was directly affected by the success or failure of a program. It is because these activities were limited by the period of the activity program rolled out by the agency implementing the program. The HEPP electrical energy development program in Pantai Baru was initially funded by the Ministry of Research and Technology's central government during the 2010-2014 program period. In 2015-2016, this activity program was delegated to the Government of Bantul Regency. Furthermore, in 2017, this activity program was officially delegated to the government of the Special Province of Yogyakarta. For an activity program to be able to impact people's welfare, it is necessary to reduce the model strategy built to facilitate the actors in the model to achieve the activity program's objectives. Besides, the usefulness of electricity beneficiaries to reduce the strategy is to make it easier to analyze the obstacles faced in implementing a program in the field.

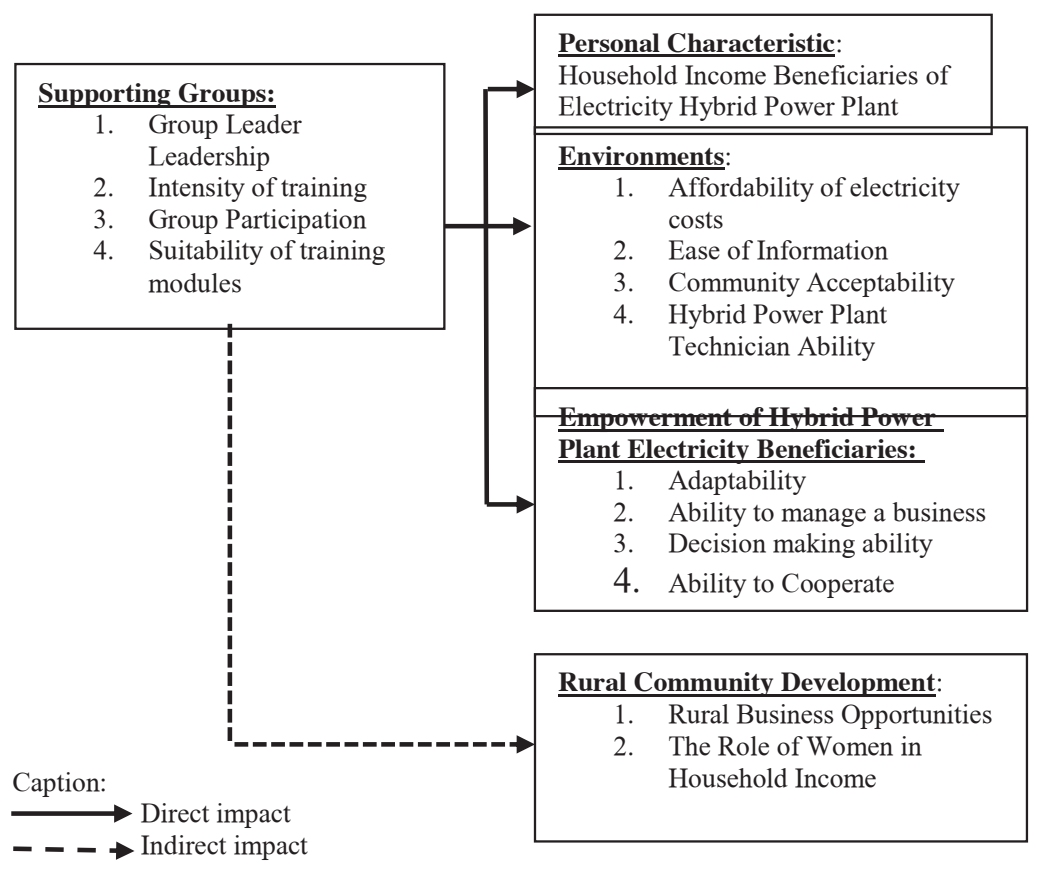

Fig.1 Community Empowerment Model with the Development of Renewable Electricity Energy HEPP in Pantai Baru. (Source: Rachmawatie, 2019) 


\section{Conclusion}

Based on the Structural Equation Modeling - Partial Least Square model, four pathways directly affected the empowerment level of HEPP electricity beneficiaries: group support for individual characteristics, group support for the environment, group support for the level of empowerment, and the empowerment level of HEPP electricity beneficiaries towards the development of village communities. Therefore, one of the variables was very direct and significant to the variables of individual characteristics, environment, and sustainability level. Thus, the factor supporting HEPP electricity beneficiaries' sustainability level in Pantai Baru was community groups' role.

In the framework of consistency and sustainability of HEPP electrical energy development activity programs in the long term so that the impact of the HEPP availability can continue to increase the empowerment of HEPP electricity beneficiaries and encourage the development of local village communities, it is crucial to formulate community empowerment models by developing electrical energy. The process of empowering the community is a necessary effort to increase individuals' ability or capacity. This effort can be done by providing motivation, outreach, training, and skills, and increasing group participation and the importance of conforming the training modules to group needs. The Community Empowerment Strategy Model in HEPP Electric Energy Development is needed to maintain the HEPP activities and tourism business activities' consistency and sustainability in Pantai Baru. The existence of HEPP and the currently developing tourism sector cannot be separated from one another because both have historical value relationships for the Ngentak Hamlet residents. Besides, the development of HEPP electricity in Pantai Baru emphasizes the socio-cultural approach, namely understanding the local community's values, traditions, and culture. It does not eliminate the order of existing values but develops HEPP electrical energy in Pantai Baru.

\section{References}

1. J. Stewart, Empowering People (Pustman Publishing, London, 1994).

2. I. Abraham, Final Report on the Review of Preparation of the Regional Electricity General Plan (RUKD) (Yogyakarta, 2016).

3. S. Humairah, Performance Report 2017 (Jakarta, 2017).

4. J. B. Fulzele and M. B. Daigavane, Mater. Today Proc. 5, 810 (2018).

5. S. Martosaputro and N. Murti, Energy Procedia 47, 273 (2014).

6. K. Y. Lau, M. F. M. Yousof, S. N. M. Arshad, M. Anwari, and A. H. M. Yatim, Energy 35, 3245 (2010).

7. S. Rehman and L. M. Al-Hadhrami, Energy 35, 4986 (2010).

8. A. H. Mondal and M. Denich, Energy Sustain. Dev. 14, 48 (2010).

9. D. Rachmawatie, E. Rustiadi, A. Fauzi, and B. Juanda, IOP Conf. Ser. Earth Environ. Sci. 383, (2019).

10. B. P. Bastakoti, Appl. Energy 76, 145 (2003).

11. E. Colomco, S. Bologna, and D. Masera, Renewable Energy and Sustainable Development (2015).

12. S. . Khandker, D. F. Barnes, H. Samad, and N. H. Minh, Econ. Dev. Cult. Change 61, 659 (2013).

13. T. Winther, M. N. Matinga, K. Ulsrud, and K. Standal, J. Dev. Eff. 9, 389 (2017).

14. S. Thomas, Group Dynamics. Principal Material Bookfor Group Dynamics Modules 1 - 9 ., 1 st ed. (Universitas Terbuka, Jakarta, 2007).

15. B. Munir, Group Dynamics, Application in the Behavioral Sciences Laboratory (Sriwijaya University, Palembang, 2001). 